Occasionally calcification of the iliac arteries may simulate a stone, as in Fig. Io, but the linear distribution of the calcification will signify that it is in the vessel walls. If, however, it only affects a short portion it may be confused with a ureteric stone. An intravenous pyelogram in this case shows that it is remote from the line of the ureter.

The radiograph depicting a small stone impacting the urethra is of interest, as it is not often that one has the opportunity to demonstrate radiologically a calculus in that position. This stone originated in the kidney and descended down the urinary tract to become held up by the urethralo stricture (Fig. 6).

The above remarks deal with a few aspects of ureteric calculi, namely, their diagnosis and ap-c pearances. In conclusion, a stone in the ureter $\overrightarrow{\vec{F}}$ should not be considered as a separate entity, but as a manifestaiton of calculous disease affecting the? whole urinary tract. In some patients the passage $\underline{\underline{\sigma}}$ of a ureteric stone is but an incident; in others it $\frac{\bar{s}}{\overrightarrow{ }}$ may preface a chapter of further urinary disorders $\subseteq$ which, it is to be hoped, will have a happyo ending.

\title{
VALE ATQUE AVE \\ A By-way of Domestic Education in the 18th Century
}

\author{
By Dr. A. MeikLejohn
}

In the Potteries district of North Staffordshire Burslem has always been regarded as the mother of the five towns, and the first free school there was erected in 1749. Early in October 1950, almost exactly 200 years later, a university college was instituted at Keele, just a few miles distant from the original school.

The subscribers to the original free school probably had no vision of a university or even a university college for the sons and daughters of poor workmen, but Josiah Wedgwood has left us some record of his views on the education of children of the middle classes. His concern was, as it must always be for most of us, the education of his family.

Josiah Wedgwood was born at Burslem in 1730 , where as a very young child he attended the dame school to which the local children were sent " more to be out of the way of mischief than for the learning to be obtained there.' When seven years old and he could walk the distance of seven miles daily, he accompanied a group of children to $\mathrm{Mr}$. Blunt's private school at Newcastle-under-Lyme. Here the master instructed his pupils in reading, writing and arithmetic, while his wife taught the girls knitting and sewing. On the death of his father in 1739 young Joss was taken from school and apprenticed to his brother Thomas in the family potworks. So his formal education ended at the age of nine years. Forty-four years later, in 1783 , in recognition of his profound contributions to ceramic science, he was elected, at the same time as his friend Joseph Priestley, a Fellow of the Royal Society. His monument in the
Parish Church, Stoke-on-Trent, bears the inscrip-⿳亠丷⿵冂丶 tion:

Sacred to the Memory of

Josiah Wedgwood, F.R.S. and S.A. of Etruria in this county.

Born, August I 730 . Died January 3rd, I7

Who converted a rude and inconsiderable

Manufacturing into an elegant Art and Ano important part of National Commerce.

In 1764 he married his cousin Sarah Wedgwood and between 1765 and 1778 a family of four sonsoํㅡㄹ and four daughters was born to them. It is in relation to the four eldest surviving children (Richard died in infancy), Susan or Sukey (the mother of Charles Darwin), Jack, Joss and Tom that Wedgwood has recorded for us a father's thoughts on the education of his family.

As was the custom of the times, all about theô age of six or seven years were sent off to boarding school; Sukey went to Manchester while her음 brothers attended a school at Bolton conducted $>$ by the Revd Mr. Holland. This school seems to have been much in demand and vacancies not always available, for on November 8,1776 , Wedgwood writes:

'You were so obliging to tell us some time since that you could take our Son Joss under your care the next summer, which offer we shalle thankfully acept, and shall be glad if you can at the same time make room for our youngest (Tom:born 1771), who wishes to accompany his ${ }_{0}^{\circ}$ Brothers, and will be a pretty little sort of a a Scholar by midsummer.' 
A glimpse of the teaching in these schools appears here:

' The young Ladies at this School are learning Geography, and are very fond of the science. They point upon a Table or blank Paper where all the counties in Great Britain lie-where the Rivers rise, what Towns they visit and where they empty themselves into-with the several circuits, and chief Towns in each County.'

Various allusions make it clear that the teaching of basic subjects was usually the care of the master, while his wife acted as matron and supplemented the education of the girls with instruction in knitting, sewing and dancing.

At the end of term the parents attended for the display and to bring the children home for the holidays.

'We were all very much delighted with the Ball and particularly in seeing our own young sprigs perform such wonders there as you may imagine we all thought they did.'

After three years at Manchester the parents decided on a change for Sukey, then aged $10 \frac{1}{2}$ years, and Wedgwood invites the opinion of his friend and partner Thomas Bentley in London.

'Mrs. Wedgwood has half a mind to send her daughter to Derby as she does not intend to send her again to Manchester School-but she does not mean to Mrs. Latifiers, that being a High $\mathrm{Ch}$ School, and would be glad of Mrs. Bentleys opinion of Mrs. Denbys.

' Sukey is now to begin to learn Musick (the harpsichord) and to continue her Drawing, and we are perswaded Mr. Denby would take more pains in teaching her both than any common Boarding school master.'

There is no record of the reply but Sukey was sent to live with the Bentleys, where she attended a private tutor.

The progress of the boys pleased their father, but he realized their difficulties in grasping the principles of chemistry.

' The boys drink in knowledge like water, with great avidity \& quite to my satisfaction. Jack is very deep in chemical affinities, \& I have no fear of his making a tolerable progress in the science, for it is much pleasanter to him than grammer. I have some fears of the latter being neglected for this new study.

'I think I mention'd to you an idea which occur'd to me of rendering the chemical affinities, composition, decompositions, \& recompositions \&c visible. I have attempted to put it into practice \& send you a specimen below of painting the changes which take place amongst the substances employ'd in producing Prussian lixivium as an example for your correction.
'These painted, visible images will make the study pleasanter to young people, \& be easier stored up in their memory, \& perhaps with more precision than the ideas alone, without the assistance of such images.'

In our time these visible images recall Bragg's models of the structure of the silicates as revealed by X-ray diffraction.

Alarmed by the deleterious effects of school life on the health of his boys, Wedgwood brought them home in October 1779 .

'I am convinc'd that if they are confin'd again to school air, with school discipline, their healths, \& bodily strength must be diminished very considerably, if not totally lost. What I now advance is upon some years observation of their constitutions, \& not a hasty conclusion from their present indisposition. I believe early confinement, \& severe application are too unnatural not to have bad consequences in a greater or less degree upon most constitutions; but my boys I am certain cannot suffer it without great injury. You are an adept in this science, $\&$ if you will have the goodness, some time at your leisure, to communicate a few hints to me I shall be very thankfull for them.'

So in his own home at Etruria he established the Etruscan School.

'My boys are quite stout $\&$ Well, \& we have form'd a pretty regular school.

' Before breakfast we read english together in the news paper, or any book we happen to have in the course of reading. We are now reading Ferbers travels, with the globe $\&$ maps before us. After breakfast they go \& write an hour with Mr. Swift \& with this small portion of time, \& writing their french exercises \& entering some experiments which they make along with me; all of which I insist upon being written in a fair legible hand, they have improv'd more in writing in these few weeks here, than they did in the last twelve months at Bolton.

'After writing, if the weather permits, they ride, or drive their hoop, or jump over a cord, or use any exercise they please for an hour, \& the remainder of the day is fill'd up with two french lessons, \& Mr. Swift attends them here an hour in the evening for accounts, in which their sister joins with them; \& we have agreed to add four latin lessons a week to the above business, for which Mr. Byerley, \& Mr. Lomas have kindly offer'd their assistance. This last is intended only to prevent their losing what they have already learnt, 'till I have decided upon this part of their learning.

'I believe a school education has many advantages over a family one, for boys in general, but this, like other general rules, ad- 
mits of many exceptions, some of which take place with my young men.

' Their constitutions are not of the Herculean stamp, \& tho' pretty well in general, require more attention than can be paid to them at a public school. They must there be dosed alike in their learning, food, \& confinement with boys of the most athletic make, whether such doses be too little, or too much, too weak or too strong, $\&$ whether they agree or disagree with them; but at home I can regulate the food $\&$ exercise both of their bodies \& minds (I beg the minds pardon) as I find they can digest it, $\&$ add to, or diminish from either as I find it necessary.'

Moreover, apart from formal instruction he was mindful of the value of parental observation and influence in the home.

'Another material consideration for me in favor of an Etruscan educa ion is, that their morals will be in better hands than at a public school, \& one may daily, \& imperceptibly be furnishing their tender minds, as they expand \& open for instruction with such raw materials as one wishes them to improve $\&$ cultivate in future life. Besides, I can be instructing them, even by way of play $\&$ amusement, in the rudiments of chemistry $\&$ give them a turn to such studies, \& enquiries are most likely to be of use to them in their particular occupations; or if these are not determin'd, find out the bent of their minds, \& what walk in life may be most suitable for them.' By this time he had established his art and a great manufacture based on profound and accurate scientific experiment, and he was determined that these and his fame should be preserved for the commonweal of posterity. Jack was to be a gentleman farmer, while young Joss and Tom were to become partners in the business. Having so decided he had to consider the advantages and disadvantages of a liberal and functional education.

' I will just mention a few of the advantages \& disadvantages of a latin, \& classical education as they occur to me, for boys intended for genteel business, or manufacturers, but not for what are called the liberal professions of Law, Physic, Divinity or the Army.

'They would know their own language as well as the latin grammatically. May not this be acquir'd in english? The acquisition of classical knowledge is another advantage which I apprehend may be obtain'd from our excellent translations.

' The opportunity of reading all the untranslated latin authors would perhaps be no great object, and the german wo ${ }^{d}$ still be locked up to a mere latin scholar.

' The additional knowledge of the derivation of words, \& some assistance in spelling, is acknowledged; but this is learning a thousand things to make use of one.

'That a knowledge of the classicks is highly市 ornamental, in classical company \& conversa-c tions, \& that it may be usefull in the knowledge of inscriptions, motto's, \& latin quotations Io grant in its fullest extent; but diamonds may be too dearly purchac'd, nay, may become ridiculous, when ostentatiously display'd, out of place, \& character; \& even pernicious when they take up that time \& attention which should be bestow'd upon more substantial objects.

' I estimate the learning of a language equal ${ }^{\circ}$ to an apprenticeship, or learning a business at $\vec{\omega}$ least; \& therefore a serious matter where times is properly estimated. Seven years, a lawyero would tell us, is a large portion of a life, 8 . should not be misapplied.

' That time must be employ'd in education which should be devoted to learning a business, I mean from about 14 to $20, \&$ what is more $\vec{\omega}$ unfavorable still to the latter, the ideas of a long ${ }_{\circ}^{+}$ school \& classical education, \& the company kept, \& habits acquir'd there, are almost in- $\vec{z}$ compatible with a life of drudgery, as it might be deem'd by a fine classical gentleman, \& ap-⿳⺈⿴囗十 lication to business afterwards.'

As founder and first Principal of the Etruscosnco School he became responsible for framing the curriculum and course of study. The daily routineo was as follows:

' One days schooling for our own five scholars. Rise at 7 in winter when I shall ring the schoolo bell, $\&$ at 6 in summer.

'Dress \& wash half an hour.

' The boys write with Mr. Swift one hour亏 along $\mathrm{w}^{\text {th }} \mathrm{Mr}$. T. Wedgwoods (if I approve of comp $^{\mathrm{y}}$ ) in some room fitted up for the purpose at the works.

' The little girls an english lesson with their. nurse in the school, which happens to be a room near the nursery. I would instill an early habit. of going to school at stated times in the youngest $\mathrm{C}_{3}$ of our scholars as it will make it so much easier to them by as much as it seems a necessary \&응 connected part of the routine or business of the day. My young men are quite orderly in this respect since I let them know that it was in-N dispensible, $\&$ they are very good in keeping my eleventh commandment-Thou shalt not be idle.' N

' Breakfast-as school boys.

' From 9 to Io French.

'From io to I I Drawing.

' From I I to I Riding or other exercise which will include gardening-Fossiling, experiment-? ing \&c. \&c.

'Susan fills up these intervals with music융 besides her exercise. 
' From I to dinner at half past I washing \&c in order to be decent at table.

' Half past 2 Latin one hour.

' Then french one hour \& conversation in the same, in the fields, garden or elsewhere as it may happen half an hour, to 5 O'Clock.

'From 5 to 7 exercise, bagging \&c.

'At 7 Acc $^{\text {ts }}$ one hour-Supper, \& to bed at 9.

' The little lasses I had forgot they must have two more english lessons in the school, \& Kitty as much french as she can bear.'

But education did not end with school attendance for we read:

' The boys are very attentive and regular in their School hours. They make progress in their french and we have begun that language at table and I shall introduce it in a few days at
School. We already market in french and we shall certainly be great adepts before Mr. Potet (a young native tutor) leaves us.'

The fame of Wedgwood and his manufacture have endured throughout these 200 years. In his private correspondence with his friends he has permitted us to share the thoughts and anxieties of a father for the future well-being of his children. As it was then it is now, and our planned education with so-called equal opportunity for all does not altogether resolve the problems and doubts of parents. The arguments about liberal and functional education remain, and today the scope and content of the teaching of technology in the universities is a major issue.

Vale! Etruscan School; Ave! University College of North Staffordshire.
NOTE

\section{ROYAL COLLEGE OF SURGEONS OF IRELAND}

\section{CARMICHAEL PRIZE ESSAY}

The late Richard Carmichael, Esq., having bequeathed to the College a sum of money for the purpose of founding prizes for essays upon certain subjects specified by him, the President and Council hereby give notice that on the second Thursday in June in the year 1952 they will proceed to adjudge prizes of $\oint_{150}$ and $£_{100}$ for the best essays that may be presented to them in accordance with the following instructions prescribed by Mr. Carmichael.

I. The state of the medical profession in its different departments of physic, surgery and pharmacy, in Great Britain and Ireland, at the time of the writing of these prize essays.

2. The state of the hospitals and schools of medicine, surgery and pharmacy.

3. The state and mode of examination, or of testing the qualifications of candidates of the different licensing colleges or corporations of medicine, surgery and pharmacy.

Under these heads the authors will be pleased to make such suggestions as may occur to them respecting the improvement of the profession with the view of rendering it more useful to the public and a more respectable body than it is at present. In these suggestions the authors will be pleased to consider the preliminary and moral education of medical and surgical students, as well as the mode of conducting their professional studies.

In considering the third head, or mode of testing the qualifications of candidates by the licensing bodies, the authors will please to consider the moss practical mode of rendering the examination as? demonstrative as possible, i.e. in anatomy, by having the dead subject placed before the candidate; in chemistry, botany and pharmacy, specimens of minerals, plants and pharmaceutical preparations placed before him; and in the practice of physic and surgery, the candidate to be placed before the patients in the wards of a hospital, as the testator is certain that this will afford the most certain and only true mode of ascertaining the qualifications of candidates.

Each essay is to be distinguished by a device or motto, and accompanied by a sealed packet containing the name and address of the author, also distinguished by the same device or motto. The essays are to be lodged at the College on or before the first day of February 1952.

No essay shall exceed 65,000 words in length, and all quotations and extracts from any published work, pamphlet or paper shall be by reference merely to the volume and page on which the passage desired to be quoted is to be found.

The President and Council will not consider themselves bound to award the prizes should the essays not appear to them to possess sufficient merit.

\section{By Order of the Council, Norman RaE, Registrar.}

Dublin, January ı6, 195 I. (n) 